\title{
SUBSTANTIATION OF EMULSION HOMOGENIZATION MODES AND THEIR CONTENT IN THE COMPOSITION OF PROTEIN-FATTY GRANULATED COTTAGE CHEESE
}

\author{
I. Ustymenko, G. Polischuk
}

National University of Food Technologies

\begin{tabular}{|c|c|}
\hline Key words: & ABSTRACT \\
\hline $\begin{array}{l}\text { Protein-fatty } \\
\text { Granulated cottage cheese } \\
\text { Emulsion } \\
\text { Blend oil } \\
\text { Emulsifying complex }\end{array}$ & $\begin{array}{l}\text { The article substantiates the technological regimes for the } \\
\text { production of emulsions and their contents in the protein-fatty } \\
\text { granular product with technologically functional and biolo- } \\
\text { gically active ingredients. The expediency of introducing } \\
\text { blended oils into a skim milk-protein base in the composition }\end{array}$ \\
\hline $\begin{array}{l}\quad \text { Article history: } \\
\text { Received 18.05.2017 } \\
\text { Received in revised form } \\
01.06 .2017 \\
\text { Accepted } 23.06 .2017\end{array}$ & $\begin{array}{l}\text { of stable, fine-dispersed food emulsions with a fat content of } \\
15 \text { to } 30 \% \text { is proved. The fat component is enriched with a } \\
\text { dietary supplement } \beta \text {-carotene. To stabilize the emulsions a } \\
\text { technologically effective "emulsifier-protein" complex in the } \\
\text { amount of } 2.90-4.25 \% \text { was used. The recommended }\end{array}$ \\
\hline $\begin{array}{l}\text { Corresponding author: } \\
\text { I. Ustymenko } \\
\text { E-mail: } \\
\text { npnuht@ukr.net }\end{array}$ & $\begin{array}{l}\text { temperature }\left(60-65^{\circ} \mathrm{C}\right) \text { and pressure of two-stage } \\
\text { homogenization }(9-10 \ldots 12-13 \mathrm{MPa} \text { on the first stage and } \\
2 \ldots 3 \mathrm{MPa} \text { on the second stage }) \text { are established depending on } \\
\text { the mass fraction of fat in emulsions. The composition of the } \\
\text { protein-fatty product, which is an analogue of granulated } \\
\text { cottage cheese, the formulation of which has } 4-6 \% \text { of fats, is } \\
\text { recommended for the production. The formulation containing } \\
7 \% \text { of fats is recommended as a basis for further expansion of } \\
\text { the range of milk-based dairy products. }\end{array}$ \\
\hline
\end{tabular}

DOI: $10.24263 / 2225-2924-2017-23-4-25$

\section{ОБГРУНТУВАННЯ РЕЖИМІВ ГОМОГЕНІЗАЦІЇ ЕМУЛЬСІЙ ТА ЇХ ВМІСТУ У СКЛАДІ ПРОДУКТУ БІЛКОВО-ЖИРОВОГО ЗЕРНИСТОГО}

\author{
І.М. Устименко, Г.Є. Поліщук \\ Національний університет харчових технологій
}

У статті обтрунтовано технологічні режими одержання емульсій та їх вмісту у складі продукту білково-жирового зернистого з технологічнофункиіональними $і$ біологічно-активними інгредієнтами. Доведено доиільність внесення купажованих олій до знежиреної молочно-білкової основи у складі стійких дрібнодисперсних харчових емульсій жирністю від 15 до $30 \%$. Жирову складову передбачено збагачувати дієтичною добавкою - $\beta$-каротином. Для стабілізації емульсій застосовано технологічно ефективний комплекс «емульгатор-білок» у кількості 2,90-4,25\%. Встановлено рекомендо- 
вані температуру $\left(60-65^{\circ} \mathrm{C}\right)$ і тиск двоступеневої гомогенізації (9-10...1213 МПа - на першому, 2...3 МПа - на другому ступені) залежно від масової частки жиру в емульсіях. Розроблено склад білково-жирового продукту аналогу сиру кисломолочного зернистого, рецептури якого жирністю 4-6\% рекомендовані до впровадження у виробнищтво, а рецептура жирністю 7\% рекомендована як базова для подальшого розширення асортименту молоковмісних продуктів закусочного і десертного призначення.

Ключові слова: продукт білково-жировий, сир кисломолочний зернистий, емульсія, купажована олія, емульгуючий комплекс.

Постановка проблеми. На сучасному етапі розвитку молочної промисловості в умовах економічної кризи та підвищеного попиту на біологічно повноцінні харчові продукти, актуальним напрямком є створення їх нових видів на молочній основі $[1 ; 2]$. Найчастіше для розроблення білково-жирових продуктів як білкову основу застосовують сир кисломолочний різних способів одержання [3].

Сир кисломолочний є джерелом повноцінного білка і кальцію, який рекомендують вживати як дієтичний продукт не лише дітям і літнім людям, але й пацієнтам після важких хвороб [4]. Амінокислоти комплексу молочних білків сприяють зміцненню імунної системи організму, регулюють жировий обмін і рівень гемоглобіну в крові. Кальцій, що міститься у сирі, сприяє формуванню здорових міцних кісток і зубів, перешкоджає появі остеопорозу, атрофії кісткової маси, рахіту та ін. $[5 ; 6]$.

Серед традиційних видів сиру кисломолочного, що користуються постійно зростаючим попитом, вагоме місце належить сиру зернистому. Цей сир відрізняється оригінальними органолептичними показниками та підвищеною харчовою цінністю, а перетравлюваність його білків становить 95\%. Ніжний смак продукту обумовлюється м'якими сирними зернами, вкритими вершками. Нині обсяги виробництва сиру зернистого у світі досягають 5\% від обсягу усіх вироблених кисломолочних сирів і щороку зростають [7], однак його вартість доволі висока, а жирнокислотний склад потребує коригування. Зважаючи на вказане, розробка складу і технології білково-жирового зернистого продукту з немолочними жирами, дешевшими за молочний жир та оригінальними органолептичними показниками, $є$ доволі актуальним завданням.

Натомість основними недоліками технології молоковмісних продуктів $\epsilon$ нерівноцінна заміна молочного жиру на жировмісну сировину і продукти іiі перероблення 3 точки зору біологічної цінності та безпечності, а також недосконалі способи внесення жирового компоненту до складу білкового продукту, які не гарантують одержання високого ступеня дисперсності і стійкості емульгованих часточок жиру [8].

На думку авторів, молоковмісні продукти доцільно збагачувати саме купажованими оліями різного складу, що містять значну кількість ПНЖК омега-6 та омега-3 за рекомендованих співвідношень [9]. В Україні чинним є ДСТУ 4536:2006 «Олії купажовані. Технічні умови», у якому наведено широкий асортимент сумішей олій з рафінованих і дезодорованих компонентів зі 
збалансованим жирнокислотним складом, які можна застосовувати для поєднання 3 молочно-білковою основою.

3 метою покращання органолептичних показників і харчової цінності молоковмісних продуктів як натуральний барвник, антиоксидант та дієтична добавка у складі купажів доцільно використовувати $\beta$-каротин. Цей провітамін $\epsilon$ ефективним профілактичним засобом для запобігання онкологічним та серцево-судинниим захворюванням за його споживання на рівні 5-6 мг за добу. Тому, з урахуванням добової норми споживання та покращання органолептичних властивостей, вміст вказаного провітаміну в харчових продуктах має складати від 0,001\% до 0,006\% [10-13].

Метою дослідження $є$ розробка нового виду молоковмісного продукту за типом сиру зернистого з купажованою олією, збагаченою $\beta$-каротином, та удосконалення способу внесення жирової фази у молочно-білкову основу.

Матеріали і методи. У складі харчових емульсій з масовою часткою жиру $15-30 \%$ використовували олію купажовану 3 рафінованих дезодорованих компонентів, збалансовану за жирнокислотним складом відповідно до ДСТУ 4536:2006 «Олії купажовані. Технічні умови».

За попередніми результатами досліджень для стабілізації емульсій прямого типу в діапазоні вмісту жиру від 15 до 30\% авторами обрано олеофільний емульгатор марки Т-2 (виробник - НПП «Електрогазохім», Україна) [14]. Як гідрофільний емульгуючий компонент використано казеїнат натрію (КН), виготовлений ТОВ «ДейріКо» (Україна) згідно з ТУ У 20.5-40392270003:2016 «Казеїнати сухі. Технічні умови». Авторами було доведено технологічгу доцільність одночасного застосування емульгатора Т-2 і КН у вигляді поверхнево-активного комплексу «емульгатор-білок» у кількості 2,90—4,25\% ( Т-2 $=0,25-0,4 \%+\mathrm{KH}=2,5 \ldots 4,0 \%)$.

Як натуральний барвник та антиоксидант використовували $\beta$-каротин вітчизняного виробництва (ТУ У 15.8.-32153647-009:2010 «Бета каротин») 3 розрахунку його вмісту у складі зернистого продукту комбінованого складу у кількості 0,0025\%.

Як молочно-білкову основу використовували сирне зерно, отримане зі знежиреного молока кислотно-сичужним способом, відповідно до чинних нормативних документів.

Емульсії одержували перемішуванням жирової (олія + емульгатор $+\beta$-каротин) та водної (вода+білок) фаз впродовж 10 хв за температури $(65 \pm 2)^{\circ} \mathrm{C} 3$ подальшою гомогенізацією грубодисперсної емульсії за допомогою гомогенизатора-диспергатора моделі 15M-8TA “Lab Homogenizer \& Sub-Micron Disperser" (GAULIN CORPORATION, Massachusetts, USA).

Стійкість емульсій (Y) визначали методом центрифужних пробірок центрифугуванням $10 \mathrm{~cm}^{3}$ зразків протягом 5 хв при частоті обертів $1500 \mathrm{xB}^{-1} 3$ подальшим їх нагріванням при $100^{\circ} \mathrm{C}$ протягом 3 хв і повторним центрифугуванням за тих же умов. Стійкість емульсії (\%) розраховували за формулою:

$$
Y=\frac{V \cdot 100}{10},
$$

де V - об’єм незруйнованої емульсії, см³; 10 - об’єм проби, см³. 
Середній діаметр жирових кульок (dср.) визначали мікроскопічним методом зf збільшення у 600 разів. Пробу готували 50..100-кратним розведенням дистильованою водою. За допомогою об'єкт-мікрометра визначали ціну поділок окулярної сітки і встановлювали розміри жирових кульок підрахунком розмірів жирових кульок у п'яти-семи полях зору кожного препарату з подальшим математичним обробленням результатів вимірювання за формулою:

$$
d_{c e p}=\sqrt[3]{\sum_{1}^{n} d_{i}^{3}} \frac{N}{N_{i}}
$$

де $d_{i}-$ середній діаметр жирових кульок у кожній групі, мкм; $N_{i}-$ число жирових кульок у кожній групі; $N$ - загальна кількість жирових кульок у всіх групах.

Титровану кислотність визначали відповідно до ГОСТ 3624. Органолептичні показники визначали проведенням дегустаційної оцінки досліджуваних зразків.

Результати та обговорення. Для розроблення складу продукту молоковмісного по типу сиру кисломолочного зернистого були враховані існуючі рекомендації та нормативні вимоги щодо масової частки білку та жиру в базовому продукті. Так, відповідно до рекомендацій Jon Fosse (N.D.T. ApS, Denmark) [15], масова частка білка в продукті зернистому має складати $13 \%$, масова частка жиру в діапазоні від 4 до 6\%, масова частка солі - у межах $0,7 \ldots 1,3 \%$, а масова частка вологи - $77 \ldots 81 \%$.

Для одержання аналогу сиру зернистого у складі рецептури має бути не менше $72 \%$ знежиреного сирного зерна 3 масовою часткою білку не нижче $18 \%$. Для одержання продукту 3 масовою часткою жиру від 4 до $6 \%$ та вмістом солі $1 \%$, жирність вершків, які додають до сирного зерна, повинна складати від 15 до 23\%. Натомість, зважаючи на сучасну тенденцію розширення асортименту сиру зернистого за підвищення його жирності до 7\%, масова частка жиру вершків має бути збільшена до 26\%. Саме тому для проведення наукового дослідження було обрано жирність емульсії в узагальненому діапазоні у межах від 15 до $30 \%$.

На наступному етапі дослідження було проаналізовано склад олій купажованих, які найдоцільніше застосовувати для нормалізації знежиреного сирного зерна. Такі олії мають містити, окрім низькоплавких, ще й високоплавкі фракції жирних кислот, які додатково відіграватимуть структуруючу роль у складі білково-жирового продукту.

Так, олія лляна містить значну кількість низькоплавких фракцій ПНЖК ( $\omega-6$ — до $60 \%, \omega-3$ - до 21\%), що обмежує іiі застосування у зв'язку з нестійкістю до окислювального псування. Олія оливкова містить до $85 \%$ олеїнової кислоти, тому ії доцільно поєднувати з рідкими оліями, що містять ПНЖК. Вміст олії ріпакової (7-10\% ліноленової і $13-25 \%$ лінолевої кислоти) у складі купажів обмежують (не більше 40\%) через іiі низьку здатність до рафінування та занадто специфічні органолептичні властивості. Зважаючи на вказане, з олій рафінованих дезодорованих купажованих, доцільно обрати такі: 
-соняшникову, ріпакову та пальмову (або пальмовий олеїн) олії за співвідношення 30:40:30;

-соняшникову олію та пальмовий олеїн у співвідношенні 70:30;

-соєву та пальмову олії - 60:40;

-соєву олію та пальмовий олеїн - 70:30.

Пальмовий олеїн є рідкою низькоплавкою фракцією пальмової олії з температурою плавлення $9 \ldots 24^{\circ} \mathrm{C}$. У той же час висока температура плавлення пальмової олії $\left(38 \ldots 40^{\circ} \mathrm{C}\right)$ є основним недоліком при ії застосуванні у складі молочних продуктів. Але у купажах пальмова олія певним чином наближатиме температуру їх плавлення до такої для молочного жиру. Тому найбільш перспективними, з точки зору одержання структуруючого ефекту, $є$ купажі олій «соняшникова:ріпакова:пальмова» (температура плавлення 4,1 ${ }^{\circ} \mathrm{C}$ ) та «соєва:пальмова» (температура плавлення 11,95 C), 3 яких було обрано останній, технологічно найдосконаліший варіант.

Рецептурний склад харчових емульсій різної жирності наведено у табл. 1.

Таблиия 1. Рецептури емульсій на основі купажованої олії, у кг на 1000 кг *

\begin{tabular}{|c|c|c|c|c|}
\hline \multirow{2}{*}{$\begin{array}{c}\text { Рецептурні } \\
\text { компоненти }\end{array}$} & \multicolumn{4}{|c|}{ Масова частка жиру в емульсії, \% } \\
\hline Купажована олія & 15 & 20 & 25 & 30 \\
\hline Емульгатор Т-2 & 2,5 & 200,0 & 250,0 & 300,0 \\
\hline Казеїнат натрію & 40,0 & 3,0 & 3,5 & 4,0 \\
\hline Вода & 807,5 & 35,0 & 30,0 & 25,0 \\
\hline Всього & 1000,0 & 762,0 & 716,5 & 671,0 \\
\hline
\end{tabular}

* У рецептурах не враховано вміст $\beta$-каротину, який складає для всіх рецептур 0,025 кг/1000 кг емульсії

Для одержання збагаченої емульсії послідовно готували жирову і водну фази. Жирову фазу отримували нагріванням купажованої олії до $60-65^{\circ} \mathrm{C} 3$ подальшим розчиненням у ній емульгатора Т-2 і $\beta$-каротину. Водну фазу готували розчиненням КН при температурі $40-45^{\circ}$ С. Грубодисперсну емульсію отримували додаванням підготовленої жирової суміші у розчин КН при температурі $60-70^{\circ} \mathrm{C}$ за постійного перемішування впродовж 10 хв за допомогою лабораторної мішалки. Одержану молочно-жирову суміш гомогенізували на гомогенизаторі клапанного типу за тиску 9,0-14,0 МПа на першому ступені і температурі $55-70^{\circ} \mathrm{C}$. Тиск на другому ступені приймали як $1 / 4$ від значення тиску на першому ступені. Рекомендовані до застосування у промислових умовах технологічні режими, за яких середні розміри жирових кульок не перевищують 2 мкм, а стійкість досягає 100 \%, наведено у табл. 2.

Таблиия 2. Рекомендовані технологічні режими процесу гомогенізації

\begin{tabular}{|c|c|c|c|c|}
\hline \multirow{2}{*}{$\begin{array}{c}\text { Рекомендовані } \\
\text { режими }\end{array}$} & \multicolumn{4}{|c|}{ Масова частка жиру емульсії, \% } \\
\cline { 2 - 5 } & 15 & 20 & 25 & 30 \\
\hline Тиск, МПа & $12-14$ & $11-13$ & $10-12$ & $9-11$ \\
\hline Температура, $^{\circ}$ & \multicolumn{4}{|c|}{$60-65$} \\
\hline
\end{tabular}


Вплив технологічних режимів гомогенізації на розміри жирових кульок наведено на рис. 1 i рис. 2. на прикладі емульсій 3 наменшим (15\%) і найбільшим (30\%) вмістом жиру.

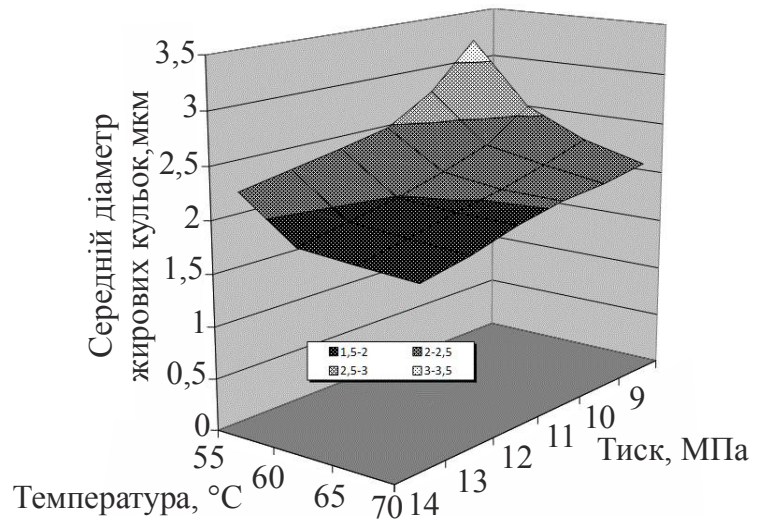

Рис. 1. Вплив режимів гомогенізації на середній діаметр жирових кульок в емульсіях 3 масовою часткою жиру $15 \%$

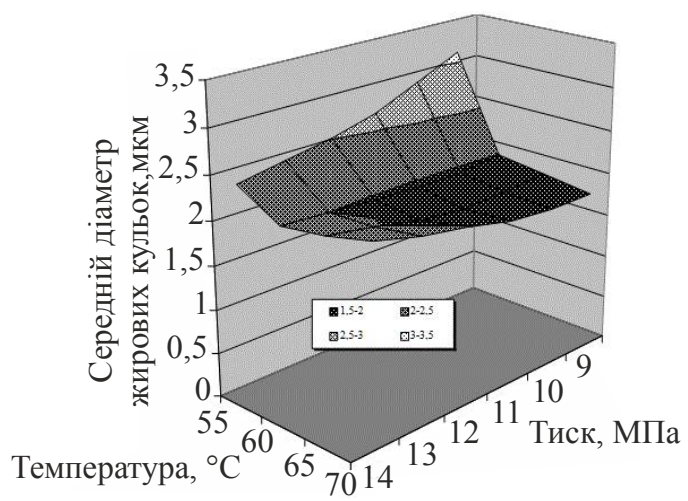

Рис. 2. Вплив режимів гомогенізації на середній діаметр жирових кульок в емульсіях з масовою часткою жиру $30 \%$

Отже, за результатами дослідження (табл. 2) встановлено, що температура гомогенізації, за якої відбувається найефективніше емульгування для всіх систем у заданому діапазоні жирності, становить не нижче $60^{\circ} \mathrm{C}$. У той же час підтверджено суттєвий вплив тиску гомогенізації на ефективність процесу залежно від масової частки жиру в емульсіях. Так, за підвищення вмісту жиру, слід знижувати тиск гомогенізації, оскільки за занадто високого тиску спостерігається навіть деяке погіршення ефективності гомогенізації. Так, у разі підвищення тиску при гомогенізації емульсії 30\%-вої жирності більше за 11 МПа на першому ступені, середній діаметр жирових кульок навіть зростав і досягав значень 2,09-2,27 мкм.

Результати дослідження, наведені на рис 1 і 2, ілюстративно підтверджують вказану закономірність, а також демонструють підвищення ефектив- 
ності процесу гомогенізації (збільшення кількості жирових кульок розмірами, що менші за 2 мкм) за зниження вмісту жирової фази. Цей ефект вказує на те, що процес диспергування жирової фази ускладнюється за збільшення іiї вмісту у дисперсній системі. Саме тому й виникає потреба у додатковому внесенні поверхнево-активних речовин для систем з підвищеним вмістом жиру.

На наступному етапі дослідження розроблено базові рецептури молочнобілкового зернистого продукту з масовою часткою жиру від 3 до 7\% на основі зерна сирного знежиреного та емульсій жирністю від 15 до 30\% (табл. 3).

\section{Табличя 3. Базові рецептури продукту білково-жирового зернистого,} кг на 1000 кг продукту

\begin{tabular}{|c|c|c|c|c|c|}
\hline \multirow{2}{*}{ Основні компоненти } & \multicolumn{5}{|c|}{ Масова частка купажованої олії, \% } \\
\cline { 2 - 6 } & 3 & 4 & 5 & 6 & 7 \\
\hline зерно сирне знежирене & 722 & 722 & 722 & 722 & 722 \\
\hline молоко знежирене & 68 & 11 & 18 & 28 & 65 \\
\hline емульсія, м.ч.ж. 15\% & 200 & 267 & - & - & - \\
\hline емульсія, м.ч.ж. 20\% & - & - & 250 & - & - \\
\hline емульсія, м.ч.ж. 25\% & - & - & - & 240 & - \\
\hline емульсія, м.ч.ж. 30\% & - & - & - & - & 233 \\
\hline сіль кухонна & 10 & 10 & 10 & 10 & 10 \\
\hline Всього & 1000 & 1000 & 1000 & 1000 & 1000 \\
\hline
\end{tabular}

Органолептичні досліджуваних зразків продукту білково-жирового зернистого наведено у табл. 4.

Таблиия 4. Органолептичні показники зразків продукту білково-жирового

\begin{tabular}{|c|c|c|c|c|c|}
\hline \multirow{2}{*}{ Показники } & \multicolumn{5}{|c|}{ Масова частка купажованої олії, \% } \\
\hline & 3 & 4 & 5 & 6 & \multirow[b]{2}{*}{$\begin{array}{c}7 \\
\text { Однорідна, з чітко } \\
\text { вираженими м’якими } \\
\text { сирними зернами, } \\
\text { вкритими густою } \\
\text { емульсією }\end{array}$} \\
\hline $\begin{array}{l}\text { Консистен- } \\
\text { ція, зовніш- } \\
\text { ній вигляд }\end{array}$ & $\mid \begin{array}{c}\text { Незначне відділення } \\
\text { емульсії від чітко } \\
\text { виражених м'яких } \\
\text { сирних зерен }\end{array}$ & \multicolumn{3}{|c|}{$\begin{array}{c}\text { Однорідна, з чітко } \\
\text { вираженими м'якими } \\
\text { сирними зернами, вкритими } \\
\text { емульсією }\end{array}$} & \\
\hline Смак і запах & \multicolumn{4}{|c|}{$\begin{array}{c}\text { Чистий, кисломолочний, приємний із солонуватим } \\
\text { смаком }\end{array}$} & $\begin{array}{c}\text { Кисломолочний, } \\
\text { приємний, з солонуватим } \\
\text { смаком і ледве відчутним } \\
\text { присмаком купажу }\end{array}$ \\
\hline Колір & $\begin{array}{c}\text { Слабко виражений } \\
\text { жовто-помаран- } \\
\text { чевий, равномірний } \\
\text { за всією масою }\end{array}$ & \multicolumn{3}{|c|}{$\begin{array}{c}\text { Помірно виражений жовтий } 3 \\
\text { помаранчевим відтінком, } \\
\text { рівномірний за всією масою }\end{array}$} & $\begin{array}{c}\text { Яскраво виражений } \\
\text { жовтий з помаранчевим } \\
\text { відтінком, рівномірний } \\
\text { за всією масою }\end{array}$ \\
\hline
\end{tabular}

Усі зразки містять не менше 13\% білка, їх титрована кислотність коливається у межах 138-148 Т, а калорійність становить від 104,8 до 121,2 ккал/100 г продукту, залежно від масової частки жиру.

За даними табл. 4 до впровадження можна рекомендувати білково-жировий продукт як альтернативу сиру кисломолочному зернистому жирністю 4 6\%. Також доцільним є подальше доопрацювання рецептури продукту 3 масовою часткою купажу 7\% для покращання його смаку і запаху. За рахунок уведення до базових рецептур смако-ароматичних гомогенних і гетерогенних 
інгредієнтів з'являється перспектива розширення асортиментного ряду біологічно повноцінної продукції закусочного і десертного призначення.

\section{Висновки}

Доведено доцільність внесення купажованих олій до знежиреної молочнобілкової основи у складі стійких дрібнодисперсних харчових емульсій жирністю від 15 до $30 \%$.

Встановлено рекомендовані температуру $\left(60-65^{\circ} \mathrm{C}\right)$ і тиск двоступеневої гомогенізації (9-10...12-13 МПа — на першому, 2...3 МПа — на другому ступені), залежно від масової частки жиру в емульсіях.

Розроблено базові рецептури білково-жирового продукту — аналогу сиру кисломолочного зернистого 3 масовою часткою жиру $4-6 \%$, які рекомендовано до впровадження.

\section{Лiтература}

1. Голубева Л.В. Влияние немолочных жиров на качество новых молокосодержащих продуктов / Л.В. Голубева, О.И. Долматова, О.Б. Стремилова та ін. // Хранение и переработка сельхозсырья. - 2012. - № 4. - С. 49-50.

2. Khodjaeva $U$. About food additives as an important part of functional food / U. Khodjaeva, T. Bojňanská, V. Vietoris, O. Sytar // Journal of Microbiology, Biotechnology and Food Sciences. Slovak University of Agriculture. 2013. — № 2. — P. 2227-2237.

3. Шульга Н.М. Вплив технологічних факторів на якість кисломолочного сиру / Н.М. Шульга, Л.А. Млечко // Молочная индустрия. — 2014. — № 1. - С. 32-35.

4. Скорченко T.A. Сир кисломолочний - компонент діабетичних видів морозива / Т.А. Скорченко, Т.Г. Федченко // Молочное дело. — 2006. — № 2. — С. $48-49$.

5. Корзун B.H. Технологія запіканок із кисломолочного сиру підвищеної харчової цінності / В.Н. Корзун, І.Ю. Антонюк // Наукові праці [Одеської національної академії харчових технологій]. — 2012. - Вип. 41(2). — С. 63-67.

6. Стеценко Н.О. Розроблення сиркової маси з рослинним наповнювачем для геродієтичного харчування [Текст] /Н.О.Стеценко // Проблемы старения и долголетия. - 2016. T. 25 , № 2. - C. $280-286$.

7. Зобкова 3.С. Особенности производства зерненого творога // Молочная промышленность. - 2008. - № 8. - С. $6-8$.

8. Ваннікова В.О. Порівняльна характеристика споживчих властивостей сиркової пасти, забагаченої омега-3 та омега-6 / В.О. Ваннікова // Праці ТДАТУ. - Вип. 14 - Т.1 Миколаїв. 2014. - С. 97-102.

9. Степьчева Н.В. Купажированные растительные масла с оптимизированным жирнокислотным составом / Н.В. Степычева, А.А. Фудько // Химия растительного сырья. 2011. — № 2. - C. 27-33.

10. Johnson E.J. The role of carotenoids in human health / E.J. Johnson // Nutrition in clinical care. - 2004. - Vol. 5. - P. 56-65.

11. Дадали В.А. Каротиноиды. Биологическая активность / В.А. Дадали, В.А. Тутельян, Ю.В. Дадали // Вопросы питания. - 2011. — № 4. - С. 70-75.

12. Rodiguez-Amaya D. HarvestPlus handbook for carotenoid analysis: Harvest technical monograph / D. RodiguezAmaya, M. Kimura. - Washington: HarvestPlus, 2004. — 58 p.

13. Сімахіна Г.О. Функціональна роль каротиноїдів та особливості їх використання у харчових технологіях // Наукові праці Національного університету харчових технологій. 2010. - № 33. - C. 45-48.

14. Полищук Г. Научное обоснование состава эмульсий для нормализации белковожировых продуктов / Г. Полищук, Г. Симахина, И. Устименко и др. // Maisto chemija ir technologija. Mokslo darbai. — 2016. — T. 50. — № 1. — Р. 45-55.

15. Сайт компанії NDT [Електронний ресурс]. - Режим доступу : http://www.ndt.$\mathrm{biz} / \mathrm{machine}$-units/cottage-cheese-production-units/cottage-cheese-technology.html. 